\title{
Osmotic Dehydration of Plantain Cultivar French (Agnrin) in Binary Solution (Sucrose or Glucose)
}

\author{
Loa Jean François Régis Bilo ${ }^{1}$, Kouamé Akissi Françoise ${ }^{1}$ and Yao N’Zué Benjamin ${ }^{2}$ \\ ${ }^{1}$ Laboratory of Food Biochemistry and Tropical Products Technologies, Dept. of Food Science \\ and Technology, Nangui-Abrogoua University, 02 BP 801 Abidjan 02, Côte d'Ivoire, Africa \\ ${ }^{2}$ Dept. of Agroforesterie, University Jean Lorougnon Guede, BP 150 Daloa, Côte d'Ivoire, Africa \\ *Corresponding author
}

\begin{tabular}{|c|c|}
\hline & A B S T R A C T \\
\hline Keywords & \multirow{4}{*}{$\begin{array}{l}\text { The objective of this work was to study the influence of parameters (temperature, solute } \\
\text { and concentration) on kinetics of water loss (WL) and on interaction effect of these } \\
\text { parameters on water loss (WL), solute gain (SG) and weight reduction (WR) on osmotic } \\
\text { dehydration of plantain cultivar French. The study was carried out using a factorial } \\
\text { experimental design. This experimental design was composed of two factors with three } \\
\text { levels and one factor with two levels, which gives a total of } 18 \text { tests to be carried out. } \\
\text { Three parameters were considered: solute (glucose and sucrose), temperature }(30,50 \text { and } \\
70{ }^{\circ} \mathrm{C} \text { ) and concentration ( } 50,60 \text { and } 70{ }^{\circ} \text { Brix). Results showed that the increase of the } \\
\text { concentration of solution and the temperature entraine an increase of WL. WL varies from } \\
16.06-42.06 \% \text { and } 18.48-44.87 \% \text { respectively with glucose and sucrose. WL, SG and WR } \\
\text { after } 8 \text { h of immersion of the whole of the } 18 \text { tests were respectively of } 36.41-65.86 \% \text {; } \\
66-19.66 \% \text { and } 22.52-50,40 \% \text {. Sucrose gives the most important water losses that } \\
\text { glucose. The factors taken into account in this study (solute, temperature and } \\
\text { concentration) showed significant effects on WL, SG and WR of plantain. }\end{array}$} \\
\hline $\begin{array}{l}\text { Osmotic } \\
\text { dehydration, } \\
\text { Plantain, } \\
\text { Experimental } \\
\text { design, Influence of } \\
\text { parameters. }\end{array}$ & \\
\hline Article Info & \\
\hline & \\
\hline
\end{tabular}

\section{Introduction}

Plantain is a basic food for the populations of some African countries. It is an excellent minerals source (iron and potassium), of vitamins (K, C, A and B6) of fibers and carbohydrates. It constitutes in particular a significant source of income for the populations which cultivate it. The annual production of plantain from Côte d'Ivoire is estimated at 1.6 million tons, which classifies it in the 3rd position of food-producing behind yam and rice (FAO, 2012).

Generaly, the pulp of Plantain is directly used for the transformation. The conservation of pulp is generally done by drying. Pulp is cut out in section and is dehydrated by drying, to obtain cossettes or is crushed to obtain flour (Ukhum and Ukpebor, 1991). Drying is usually a long process that requires high temperatures, leading to degradation and oxidation of some nutrients. Other techniques such as osmotic dehydration are also used to reduce or eliminate partially water in food.

Osmotic dehydration (OD) can be considered as an important step prior to drying, since it provides a reduction in nutrient losses and an improvement in product quality (Mandala et 
al., 2005; Riva et al., 2005). In such processes, the product is soaked in a hypertonic solution, where two main countercurrent mass transfer flows take place: a water flow from the product to the solution and a solute migration from the solution to the product. OD consists of partial elimination of water contained in a food by immersing it in a hypertonic solution of sugar and / or salt (Shingh and Meheta, 2008). It has several advantages such as the stabilization of color, conservation of flavor (Mavroudis et al., 2005). Several studies have been conducted on the OD of many fruits and vegetables, authors such as Derossi (2015) have worked on the DO of tomato sauces; Fernades (2008) on melon; Kejian Zou (2013) on mango chips; Amami (2005) on potatoes; N'goran (2012) on tropical fruits (mango and papaya). Particularly for bananas, the OD has focused on the Cavendish variety (Mauro and Menegalli 1995; Rastogi et al., 1997; and Fernandes et al., 2006). However, few studies have focused on plantain. It is important to point out that plantain occupies the third place of food products in Côte d'Ivoire. The cultivars most cultivated in Côte d'Ivoire are the cultivar Corne and the cultivar French (Agnrin), they represent $90 \%$ of the production (N'Da Adopo, 1998).

The objective was to analyse the influence of temperature, solute and concentration of the osmotic solution on the mass transfer process during the osmotic dehydration of cultivar French (Agnrin), in order to propose the osmotic dehydration as an alternative conservation solution or pretreatment method for the conservation of this cultivar.

\section{Materials and Methods}

\section{Preparation of Sample}

Plantains (French) were purchased from a local market. They were selected according to the quality attributes: color (yellow), uniformity, solids solubles $\left(8-9{ }^{\circ}\right.$ Brix $)$, water content $(63-65 \%)$.

\section{Osmotic dehydration}

For the osmotic dehydration, sucrose and glucose solutions with 50, 60 and $70{ }^{\circ}$ Brix were used at three different temperatures (30, 50 and $\left.70{ }^{\circ} \mathrm{C}\right)$. Plantain was cut, weighed $(10$ g) and immersed whole into the osmotic solution in glass jars, which were then covered with lids to reduce moisture loss. The solution-to-sample ratio is $10: 1(\mathrm{w} / \mathrm{v})$. The process was carried out for $8 \mathrm{~h}$. Fruits were removed from the jars at 1-h intervals, quickly rinsed and gently blotted with tissue paper to remove excess solution from the surface, then weighed and returned to the osmotic solution to continue the dehydration process. Each experiment was carried out in triplicate. Water loss (WL), Weight reduction (WR) and solid gain (SG) of the sample was calculated based on its weight, moisture content, according to following Equations:
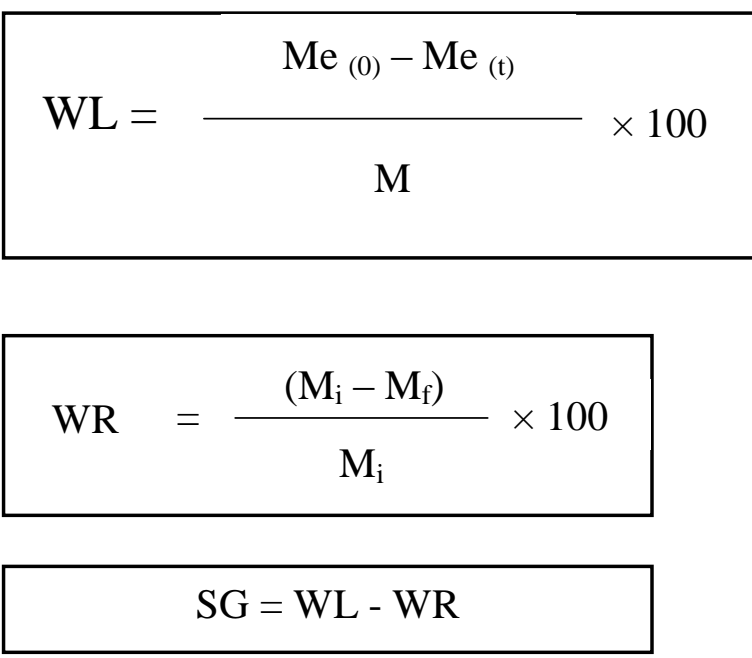

With: WL: water loss, WR: weight reduction, SG: solids gain. Me (0): mass of water of the sample before treatment, $M(t)$ : mass of water of the sample after treatment at time $t, M$ : initial mass of the sample before treatment, Mi: initial mass of the fruit, Mf: final mass of the fruit. 


\section{Experimental design}

A factorial design on mixed levels was used to carry out this experimentation, it composite to three factors (independent variables): solute (sucrose and glucose), temperature $(30,50$ and $70^{\circ} \mathrm{C}$ ) and solution concentration $(50,60$ and $70 \%$ ). This experimental design includes two factors with 3 level and one factor with 2 level, giving a total of 18 tests. Table 1 presents the matrix experimental, the coded values $\mathrm{X} 1, \mathrm{X} 2$ and $\mathrm{X} 3$ respectively designate the solute, the temperature and the concentration of the solution.

Table 1 summarizes all 18 tests to be carried out. Each test carried out depends on the experimental conditions described in this Table. Thus, water loss (Y1), solute gain (Y2) and weight reduction (Y3) are the responses taken into account and given by the following equation:

$$
Y=f\left(X_{1}, X_{2}, X_{3}, X_{4}\right)
$$

From the expected responses of the different tests, the global effect, principal and interaction effects of the different factors were calculated using the multiple linear regression equation performed by Microsoft Excel 2013 software (Microsoft Inc. Texas, USA). A coefficient is significant if its probability is less than $10 \%$ (Feinberg, 1996). The first column of Table 1 shows the tests, the next three columns represent the coded values of the tests and the last three columns indicate the reel values of the tests.

\section{Results and Discussion}

\section{Influence of process variables}

\section{Influence of solute concentration}

Fig. 1 and 2 show respectively the influence of the concentration of glucose and sucrose on the water loss of plantain. With glucose (Fig. 1), WL varies from 16.06 to $42.06 \%$ and with sucrose (Fig 2.), WL varies from 18.48 to $44.87 \%$. According to FIGS. 1 and 2, the increase in the concentration of the osmotic solution leads to a significant $(\mathrm{p}<0.05)$ increase in WL. The highest water losses for both solutes (sucrose and glucose) are obtained at $70{ }^{\circ}$ Brix. Similar results have been reported by Fernandes et al., (2008); Ismail et al., (2007) and N'goran et al., (2012) in their respective studies on melon, potato and tropical fruits (mango and papaya). According to Ispir and Togrul (2009), the increase in the concentration gradient leads to an increase in the osmotic pressure exerted by the solution on the fruit, which leads to a higher water loss.

\section{Influence of temperature}

The influence of temperature on the water loss is illustrated by Figs. 3 and 4. According to these figures, WL are not significantly different between 30 and $50{ }^{\circ} \mathrm{C}$, which explains why the curves of $30^{\circ} \mathrm{C}$ and $50{ }^{\circ} \mathrm{C}$ are almost confused. On the other hand, WL increases significantly for both solutes between 50 and $70{ }^{\circ} \mathrm{C}$. Temperature has a significant influence $(\mathrm{p}<0.05)$ on the duration of osmotic dehydration. WL after $1 \mathrm{~h}$ of treatment at $70{ }^{\circ} \mathrm{C}(26.43 \%)$ are obtained after $3 \mathrm{~h}$ of treatment at $30{ }^{\circ} \mathrm{C}(26.25 \%)$ and at $50{ }^{\circ} \mathrm{C}(27.57 \%)$. The increase in the temperature of the osmotic solution does not systematically lead to an increase in the water loss. Similar results have been reported by Chenlo (2006). The influence of temperature in the OD phenomenon divides many authors. Some authors such as Sablani and Shafur Rahman, (2003) and Corzo and Gomez, (2004) have shown in their work that temperature does not have a significant effect on OD, whereas other authors such as Khoyi et al., (2007); Azoubel et al., (2008) estimate that the increase in temperature leads to an 
increase in water loss. The debatable effect of temperature on the OD would explain the variation of the influence of temperature between $30{ }^{\circ} \mathrm{C}$ and $50{ }^{\circ} \mathrm{C}$ observed.

\section{Influence of solute}

The study of the influence of the type of solute on the water loss during OD was carried out with sucrose and glucose (FIG. 5), the water losses obtained with sucrose are higher than those of glucose throughout the treatment. Significant differences between the water losses of these two solutes were observed from the 4th hour. Sucrose seems to be the ideal solute for OD. The influence of the type of solute could be explained by the size and the molecular weight of the solute. Low molecular weight molecules result in low water loss as high molecular weight solutes (Dermesonlouoglou, 2007). Sucrose with a molecular weight of $342.3 \mathrm{~g}$ compared with $182 \mathrm{~g}$ for glucose, obviously gives greater water losses than glucose.

Fig.1 Influence of glucose concentration

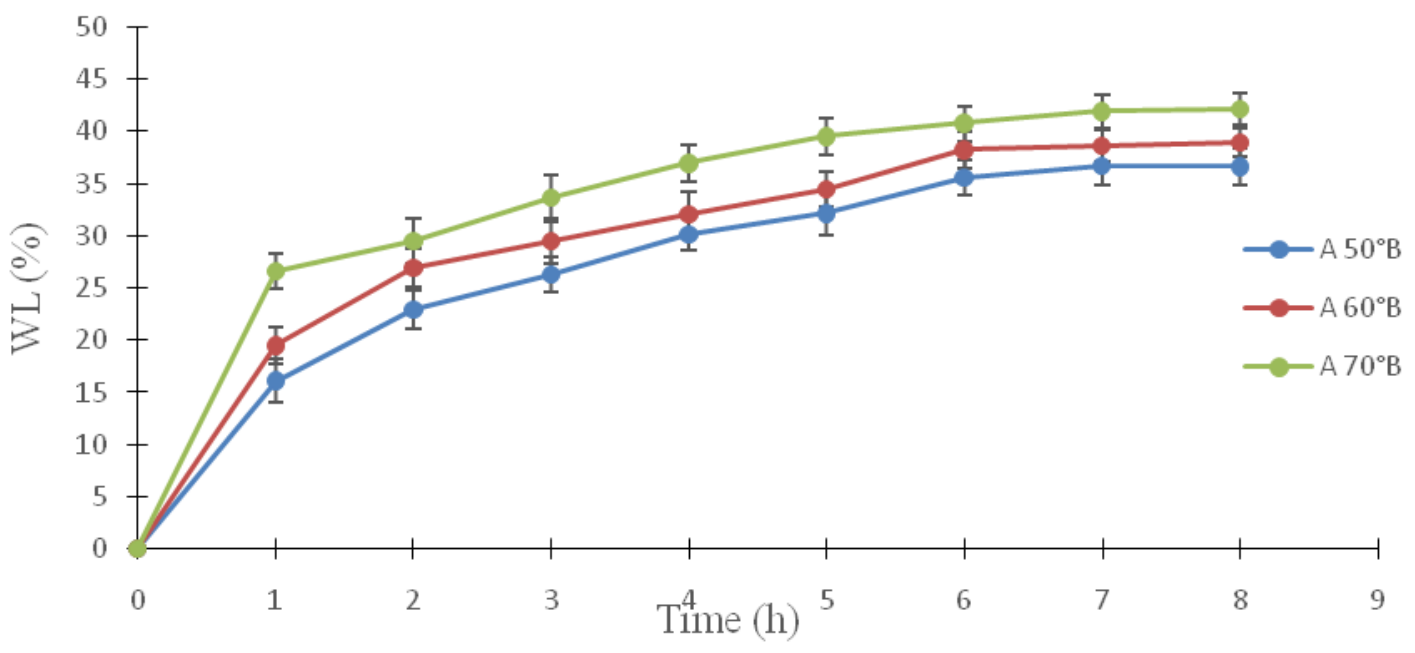

Fig.2 Influence of sucrose concentration

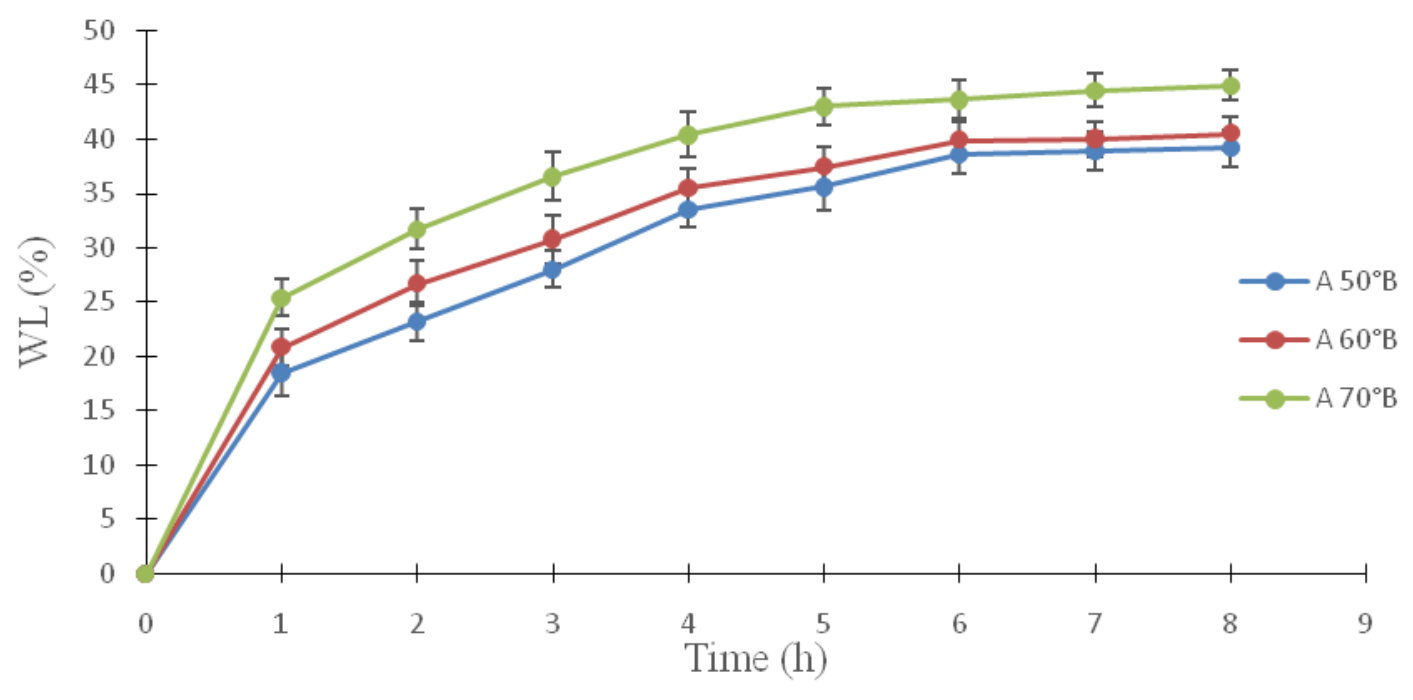


Fig.3 Influence of the température on OD with glucose $\left(50{ }^{\circ} \mathrm{B}\right)$

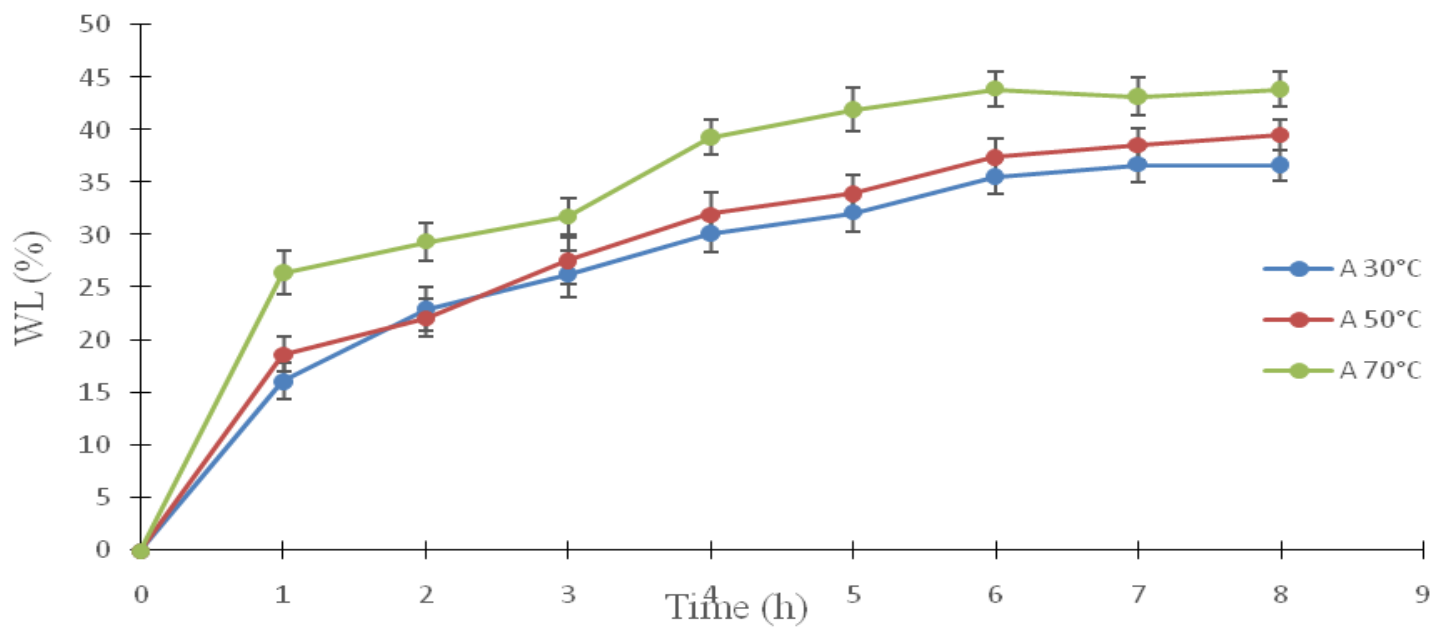

Fig.4 Influence of the température on OD with sucrose $\left(50^{\circ} \mathrm{B}\right)$

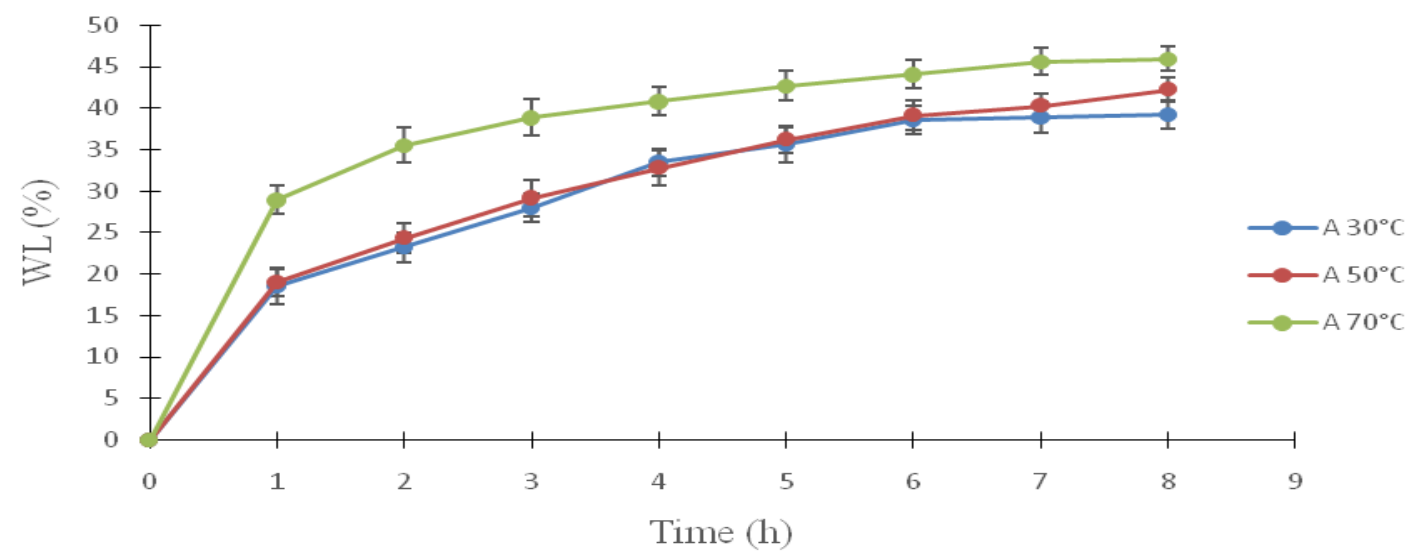

Fig.5 Influence of solute

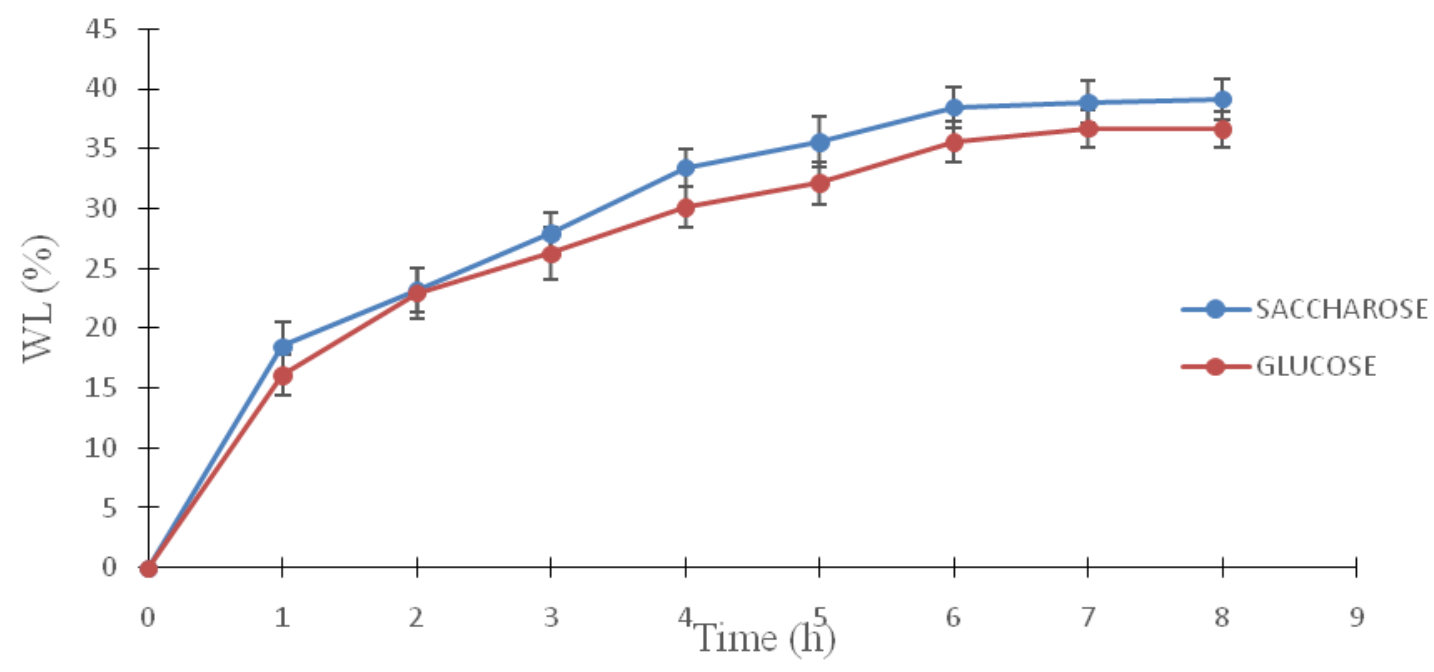


Table.1 Matrix of tests of OD of plantain

\begin{tabular}{cccc|lcc}
\hline \multicolumn{5}{c}{ Coded values } & & \multicolumn{3}{c}{ Reel values } \\
\hline Tests & $\mathbf{X}_{\mathbf{2}}$ & $\mathbf{X}_{\mathbf{3}}$ & $\mathbf{X}_{\mathbf{4}}$ & Soluté & $\begin{array}{c}\text { Température } \\
\left({ }^{\circ} \mathbf{C}\right)\end{array}$ & $\begin{array}{c}\text { Concentration } \\
\left({ }^{\mathbf{B}} \mathbf{B r i x}\right)\end{array}$ \\
\hline 1 & 1 & -1 & -1 & Saccharose & 30 & 50 \\
2 & 1 & -1 & 0 & Saccharose & 30 & 60 \\
3 & 1 & -1 & 1 & Saccharose & 30 & 70 \\
4 & 1 & 0 & -1 & Saccharose & 50 & 50 \\
5 & 1 & 0 & 0 & Saccharose & 50 & 60 \\
6 & 1 & 0 & 1 & Saccharose & 50 & 70 \\
7 & 1 & 1 & -1 & Saccharose & 70 & 50 \\
8 & 1 & 1 & 0 & Saccharose & 70 & 60 \\
9 & 1 & 1 & 1 & Saccharose & 70 & 70 \\
10 & -1 & -1 & -1 & Glucose & 30 & 50 \\
11 & -1 & -1 & 0 & Glucose & 30 & 60 \\
12 & -1 & -1 & 1 & Glucose & 30 & 70 \\
13 & -1 & 0 & -1 & Glucose & 50 & 50 \\
14 & -1 & 0 & 0 & Glucose & 50 & 60 \\
15 & -1 & 0 & 1 & Glucose & 50 & 70 \\
16 & -1 & 1 & -1 & Glucose & 70 & 50 \\
17 & -1 & 1 & 0 & Glucose & 70 & 60 \\
18 & -1 & 1 & 1 & Glucose & 70 & 70 \\
\hline
\end{tabular}

Table.2 Experimental designs and values of WL, SG and WR after $8 \mathrm{~h}$ of immersion

\begin{tabular}{ccccccc}
\hline Tests & Solute & $\begin{array}{c}\text { Temperature } \\
\left({ }^{\circ} \mathbf{C}\right)\end{array}$ & $\begin{array}{c}\text { Concentration } \\
\left({ }^{\circ} \mathbf{B r i x}\right)\end{array}$ & WL $(\boldsymbol{\%})$ & SG $(\boldsymbol{\%})$ & WR $(\boldsymbol{\%})$ \\
\hline 1 & Sucrose & 30 & 50 & 39,12 & 12,66 & 26,46 \\
2 & Sucrose & 30 & 60 & 40,46 & 13,13 & 27,33 \\
3 & Sucrose & 30 & 70 & 44,87 & 15,77 & 29,10 \\
4 & Sucrose & 50 & 50 & 42,19 & 16,58 & 25,61 \\
5 & Sucrose & 50 & 60 & 59,90 & 15,17 & 44,73 \\
6 & Sucrose & 50 & 70 & 55,78 & 16,33 & 39,45 \\
7 & Sucrose & 70 & 50 & 45,90 & 15,68 & 30,22 \\
8 & Sucrose & 70 & 60 & 60,10 & 15,34 & 44,76 \\
9 & Sucrose & 70 & 70 & 65,86 & 15,46 & 50,40 \\
10 & Glucose & 30 & 50 & 36,41 & 12,73 & 24,08 \\
11 & Glucose & 30 & 60 & 38,93 & 16,41 & 22,52 \\
12 & Glucose & 30 & 70 & 42,07 & 16,33 & 25,74 \\
13 & Glucose & 50 & 50 & 39,54 & 17,76 & 21,78 \\
14 & Glucose & 50 & 60 & 50,62 & 18,32 & 32,30 \\
15 & Glucose & 50 & 70 & 53,48 & 18,66 & 34,82 \\
16 & Glucose & 70 & 50 & 43,87 & 16,66 & 27,21 \\
17 & Glucose & 70 & 60 & 55,69 & 19,25 & 36,44 \\
18 & Glucose & 70 & 70 & 63,45 & 19,66 & 43,79 \\
\hline
\end{tabular}


Table.3 Effect of factors on WL, SG and WR of plantain

\begin{tabular}{lcc|cc|cc}
\hline & \multicolumn{2}{c|}{ WL } & \multicolumn{2}{c|}{ SG } & \multicolumn{2}{c}{ WR } \\
\hline & Coeff & $P$ & Coeff & $P$ & Coeff & $P$ \\
\hline Constante & 48,79 & $\mathbf{0 . 0 0 0}$ & 16.21 & $\mathbf{0 , 0 0 0}$ & 32.59 & $\mathbf{0 , 0 0 0}$ \\
Solute $(\mathrm{S})$ & 1,67 & $\mathbf{0 . 0 7 8}$ & -1.09 & $\mathbf{0 . 0 0 4}$ & 2.74 & $\mathbf{0 . 0 1 1}$ \\
Temperature $(\mathrm{T})$ & 7,75 & $\mathbf{0 . 0 0 0}$ & 1.25 & $\mathbf{0 . 0 0 5}$ & 6.46 & $\mathbf{0 . 0 0 0}$ \\
Concentration $(\mathrm{C})$ & 6,54 & $\mathbf{0 . 0 0 0}$ & 0.84 & $\mathbf{0 . 0 4 0}$ & 5.66 & $\mathbf{0 . 0 0 0}$ \\
$\mathrm{S} \times \mathrm{T}$ & 0,15 & 0.888 & -0.43 & 0.258 & 0.61 & 0.583 \\
$\mathrm{~S} \times \mathrm{C}$ & 0,01 & 0.992 & -0.4 & 0.287 & 0.44 & 0.688 \\
$\mathrm{~T} \times \mathrm{C}$ & 3,51 & $\mathbf{0 . 0 2 0}$ & -0.49 & 0.291 & 4.05 & $\mathbf{0 . 0 1 0}$ \\
$\mathrm{S} \times \mathrm{T} \times \mathrm{C}$ & 0,03 & 0.977 & -0.34 & 0.457 & 0.32 & 0.810 \\
\hline
\end{tabular}

Coeff: coefficience; P: probability

Experimental design for the osmotic dehydration tests

Results of different runs of osmotic dehydration are shown in Table 2 . WL is between 36.61 and $65.56 \%$. According to Table 2, the highest WL are obtained in test 9 , the solute used in this test is sucrose and the temperature and concentration are taken at their highest levels $\left(70{ }^{\circ} \mathrm{C}\right.$ and $\left.70{ }^{\circ} \mathrm{Brix}\right)$. On the other hand, the lowest WL are obtained in test 10 , where the solute is glucose and the temperature and concentration are at their lowest levels $\left(30^{\circ} \mathrm{C}\right.$ and $\left.50{ }^{\circ} \mathrm{B}\right)$. The lowest WR were obtained in test 13 , with glucose 50 ${ }^{\circ} \mathrm{C}$ and $50{ }^{\circ} \mathrm{B}$ and the highest WR were obtained in test 8 with sucrose at $70{ }^{\circ} \mathrm{C}$ and $60{ }^{\circ} \mathrm{B}$. For SG, Test 1 gives the lowest SG where the solute is sucrose and the temperature and concentration are at their lowest $\left(30^{\circ} \mathrm{C}\right.$ and $\left.50{ }^{\circ} \mathrm{B}\right)$. On the other hand, the highest $\mathrm{SG}$ are obtained in test 18 with glucose at $70{ }^{\circ} \mathrm{C}$ and $70{ }^{\circ} \mathrm{B}$ Generally, the highest WL and WR masses were obtained under the optimum conditions. With regard to the gain of solute, the highest were obtained with glucose as solute. Similar results have been reported by Fadale et al., (2007); N'goran et al., (2012). According to RaoultWack (1994), the concentration gradients generated during the OD result in a double cross transfer of matter: the water is released from the product to the solution (dehydration) and the solute enters the solution into the food impregnation).

\section{Effect of factors on WL, SG and WR of plantain}

Table 3 shows that all factors (solute, temperature and concentration) have a positive and significant influence $(p<0.1)$ on WL and WR during the osmotic dehydration of the banana. The effects of interactions have a positive influence, but only the interaction of order 2 temperature-concentration is significant $(\mathrm{p}<0.1)$. Similar results have been reported by Singh et al., (2010); Mercali et al., (2011); N'goran et al., (2012). The increase in temperature facilitates the transfer of matter and the high concentrations increase the water loss. With regard to SG, only the temperature and the concentration of the osmotic solution had a positive and significant influence $(p<0.1)$ on the SG of the plantain. The influence of temperature and concentration on solute gain during OD has been reported by several authors (Singh et al., 2007; Eren et al., 2007; Singh et al., 2010; Mercali et al., 2011 and N'goran et al., 2012).

The study of osmotic dehydration of plantain (French cultivar) consisted in evaluating the influence of parameters such as concentration, 
temperature and type of solute on the loss of water. This study shows that increasing the concentration and temperature of the osmotic solution leads to an increase in water loss. Sucrose gives the most important water losses that glucose. The factors taken into account in this study (solute type, temperature and concentration) showed significant effects on water loss, solute gain and loss of banana mass. On the other hand, only the interaction effect between concentration and temperature was both positive and significant.

\section{References}

Amami, E., Vorobiev, E. and Kechaou, N. 2005. Effect of Pulsed Electric Field on the Osmotic Dehydration and Mass Transfer Kinetics of Apple Tissue. Drying Technology: An International Journal. 23, 581-595.

Azoubel, P., and Da Silva F. 2008. Optimisation of osmotic dehydration of 'Tommy Atkins' mango fruit. International Journal of Food Science and Technology. 43, 1276-1280.

Chenlo, F., Moreira, R., Fernández-Herrero, C. and Vásquez, G. 2006. Experimental results and modeling of the osmotic dehydration kinetics of chestnut with glucose solutions. J. Food Eng. 74, 324-334.

Dermesonlouoglou, E., Giannakourou, M. and Taoukis, P. 2007. Kinetic modelling of the degradation of quality of osmodehydrofrozen tomatoes during storage. Food Chemistry. 103, 985-993.

Derossi, A., Severini, C., Del Mastro, A. and De Pilli T. 2015. Study and optimization of osmotic dehydration of cherry tomatoes in complex solution by response surface methodology and desirability approach. Food Science and Technology. 60, 641-648.

Eren, I., and Kaymak-Ertekin, F. 2007. Optimization of osmoticdehydration of potato using response surfacemethodology. Journal of Food Engineering. 79, 344-352.

Falade, K. O., Igbeka, J. C. and Ayanwuyi, F. A. 2007. Kinetics of mass transfer, and colour changes duringosmotic dehydration of watermelon. Journal of Food Engineering. 80, 979-985.

FAO. 2012. Agricultural statistics. Food and agriculture organization of the United Nations, Rome.

Feinberg, M., 1996. La Validation des Méthodes d'Analyse: Une Approche Chimiométrique de l'assurance qualité au laboratoire. Paris, France: Masson.

Fernandes, F., Gallao, M. and Sueli, R. 2008. Effect of osmotic dehydration and ultrasound pre-treatment on cell structure: Melon dehydration Food Science and Technology. 41, 604-610.

Fernandes, F., Rodrigues, S., Gaspareto, O. and Oliveira, L. 2006. Optimization of osmotique dehydration of bananas followed by air-drying. Journal of Food Engineering. 77, 188-193.

Ismail, E., and Figen, K. 2007. Optimization of osmotic dehydration of potato using response surface methodology. Journal of Food Engineering. 79, 344-352.

Ispir, A., and Togrul, I. 2009. Osmotic dehydration of apricot: Kinetics and the effect of process parameters. Chemical Engineering Research and Design. 87, 166-180.

Kejian Zou, J., Teng, L., Xinwei D. and Baoyao, W. 2013. Effect of osmotic pretreatment on quality of mango chips by explosion puffing drying. Food Science and Technology. 51, 253-259.

Khoyi, M. R., and Hesari, J. 2007. Osmotic dehydration kinetics of apricot using sucrose solution. J. Food Eng. 78, 1355-1360.

Mandala, I. G., Anagnostaras, E. F. and Oikonomou, C. K. 2005. Influence of osmotic dehydration conditions on 
apple air-dryingkinetics and their quality characteristics. Journal of Food Engineering. 69 (3), 307-316.

Mauro, M. A., \& Menegalli, F. 1995. Evaluation of diffusion coefficients in osmotic concentration of banana (Musa Cavendish Lambert). International Journal of Food Science and Technology. 30, 199-213.

Mavroudis, N.E., Gekas, V and Sjoholm, I. 2005. Osmotic Dehydration of ApplesEffects of Agitation and Raw Material Characteristics. Journal of Food Engineering. 35, 191 - 209.

Mercali, G. D., Marczak, D. F., Tessaro C., Noreña C. 2011. Evaluation of water, sucrose and $\mathrm{NaCl}$ effective diffusivities during osmotic dehydration of banana (Musa sapientum, shum.). Food Science and Technology. 44, 82-91.

N'da Adopo, A., Amafon, G., Kehe, H., Kamara, F., et Fofana, V. 1998. Les perspectives d'évolution du circuit de distribution de la banane plantain en Côte d'Ivoire. In: Banana and Food Security. International symposium, Douala, Cameroon, 10-14.

N'Goran, Z. E. B., Aw, S., Assidjo E. N. ET Kouame P. 2012. Influence des paramètres de la osmotique déshydratation sur la perte d'eau dans la papaye et al., mangue. Journal of Applied Biosciences 59, 4330- 4339.

Raoult-Wack, A. L., 1994. Recent advances in the osmotic dehydration of foods. Trends in Food Scienceand Technology. 5, 255-260.
Rastogi, N., Raghavarao, K., and Niranjan, K. 1997. Mass transfer during osmotic dehydration of banana: fickian diffusion in cylindrical configuration. Journal of Food Engineering. 31, 423-432.

Riva, M., Campolongo, S., Leva, A., Maestrelli, A., and Torreggiani, D. 2005. Structure-property relationships in osmo-air-dehydrated apricot cubes. Food Research International. 38 (5), 533-542

Sablani, S.S., and Rahman, M.S. 2003. Effect of syrup concentration, temperature and sample geometry on equilibrium distribution dehydration of mango. Food Res. Int. 36, 65-71

Singh, B. and Mehta, S. 2008. Effect of osmotic pretreatment on equilibrium moisture content of dehydrated carrot cubes. International Journal of Food Science and Technology. 43, 532-537.

Singh, B., Kumar, A. And Gupta, A.K. 2007. Study of mass transfer kinetics and effective diffusivity during osmotic dehydration of carrotcubes. J. Food Eng. 79, 471-480.

Singh, B., Panesar, P S., Nanda V, Kennedy J. 2010. Optimisation of osmotic dehydration process of carrot cubes in mixtures of sucrose and sodium chloride solutions. Food Chemistry. 123,590-600.

Ukhum, M., and Ukpebor, I. 1991. Production of instant plantain flour, sensory evaluation and physico-chemical changes during storage. Food Chemistry. 42, 287-299.

\section{How to cite this article:}

Loa Jean François Régis Bilo, Kouamé Akissi Françoise and Yao N’Zué Benjamin. 2017. Osmotic Dehydration of Plantain Cultivar French (Agnrin) in Binary Solution (Sucrose or Glucose). Int.J.Curr.Microbiol.App.Sci. 6(10): 4816-4824. doi: https://doi.org/10.20546/ijcmas.2017.610.449 